Author: M Carnelley

\title{
LIABILITY FOR THE PAYMENT OF PUBLIC SCHOOL FEES
}

\section{ISSN 1727-3781}

2011 VOLUME 14 No 6

http://dx.doi.org/10.4314/peli.v14i6.2 


\section{LIABILITY FOR THE PAYMENT OF PUBLIC SCHOOL FEES}

\section{Carnelley*}

\section{$1 \quad$ Introduction}

The South African Schools Act ${ }^{1}$ provides that "a parent is liable to pay the school fees determined in terms of section 39 unless and to the extent that he or she has been exempted from payment in terms of the Act." ${ }^{2}$ This provision prima facie confirms the common law duty on all parents to maintain their children. ${ }^{3}$ The Act, however, goes further than the common law when it defines a "parent" to mean:

(a) the parent or guardian of the child;

(b) the person legally entitled to custody of the learner; or

(c) the person who undertakes to fulfil the obligation of a person referred to in paragraphs (a) and (b) towards the learner's education at school. ${ }^{4}$

This definition was narrowly defined by the Northern Cape High Court in Bestuursraad van die Laerskool Sentraal, Kakamas $v$ Van Kradenburg. ${ }^{5}$ The court found that, with regard to the payment of school fees, the term "parent" in the SASA includes only the custodian parent and not both parents. The court based its decision on the earlier decision of the Cape High Court in Bestuursliggaam van Gene Louw Laerskool $v$ Roodtman, ${ }^{6}$ where it was found that the term "parent" in the (now repealed) Education Affairs Act (House of Assembly) ${ }^{7}$ should be interpreted to mean only the custodian parent. ${ }^{8}$

\footnotetext{
* Marita Carnelley. BA LLB (Stell) LLM (UNISA) PhD (Amsterdam). Professor of Law, University of KwaZulu-Natal (Pietermaritzburg Campus). With thanks to Rolien Roos for her insightful comments and suggestions regarding an earlier draft. E-mail: carnelleym@ukzn.ac.za.

1 South African Schools Act 84 of 1996 (hereinafter the SASA).

2 Section 40(1) SASA.

3 There is a duty on both parents to maintain their children and this duty specifically includes providing children with suitable education (s 15(2) Maintenance Act 99 of 1998; s 18(2)(d) Children's Act 38 of 2005.

4 Section 1 SASA.

5 Bestuursraad van die Laerskool Sentraal, Kakamas v Van Kradenburg 2008 JOL 21631 (NC) para 13 (hereinafter Van Kradenburg).

6 Bestuursliggaam van Gene Louw Laerskool v Roodtman 20032 All SA 87 (C) (hereinafter Roodtman).

7 Education Affairs Act (House of Assembly) 70 of 1988.

8 The court based its decision on the interpretation of the term throughout the statute (Roodtman 96).
} 
The practical implication of these cases was that a school could not, where the parents were living separately, ${ }^{9}$ claim any outstanding school fees from the noncustodian parent, unless he or she either contracted directly with the school or another foundation for the existing claim. ${ }^{10}$ Although the custodian parent remained solely liable for the school fees, he or she could nevertheless, in terms of the common law, claim from the non-custodian parent any amount paid in excess of his or her share of the maintenance of the child in general.

The Supreme Court of Appeal, in the case of Fish Hoek Primary School v GW, ${ }^{11}$ took a different view from Roodtman and Van Kradenburg. The SCA found that the definition of a "parent" in the SASA is wide enough to include any parent of the child - regardless of the relationship between the parents of the child and regardless of whether the parent has any parental authority over the child. At issue, in casu, was the payment of school fees for a child born of unmarried parents in instances where the father did not have any parental authority over the child. ${ }^{12}$ Consequently, a school could claim payment of outstanding school fees from both parents, including the non-custodian parent, regardless of the relationship or the marital status of the parents.

The principle of liability for school fees in the SASA is broadly based on the common law duty to maintain. This is, however, only one side of the coin, as the liability for school fees may also be based on a variety of other legal principles.

This article sets out to address, firstly, the issue of who is liable for paying school fees and secondly, the (other) possible bases for such a liability. In view hereof this article aims at discussing the provisions of the SASA in the light of the Children's $A c t^{13}$ and various judgments. Particular emphasis is placed on the Fish Hoek Primary School judgment, and establishing who is responsible for the educational

9 In both of these matters the parents of the children were divorced and the court had made a care (custody) order.

10 Where the non-custodian parent contracted with the school for payment of the fees, he/she would be liable in terms of the contract. See discussion infra.

11 Fish Hoek Primary School v GW 2009 JOL 24624 (SCA) (hereinafter Fish Hoek Primary School).

12 The father was neither the guardian nor the custodian of the child and there was no access or contact order.

13 Children's Act 38 of 2005. 
needs of the child at school level in instances where parties have the ability to pay school fees. The exposition goes wider than "parents," and includes references to "guardians," "custodians" and "persons who voluntary undertake the responsibility." This part of the discussion thus focuses on the common law maintenance duty of various persons as amended by statute. The second aim is to extend the enquiry to other possible legal foundations for claims by the school in their pursuit of the payment of school fees, which include a claim based on contract, the concept of household necessaries, stipulatio alteri, negotiorum gestio and unjustified enrichment.

Certain issues are deliberately excluded from this discussion, namely the choice of school, ${ }^{14}$ the process of the determination of the school fees at a particular school, ${ }^{15}$ the possible exemptions granted to indigent parents from the obligation to pay school fees, ${ }^{16}$ an increase of the fees subsequent to enrolment, ${ }^{17}$ the issue of school fees at private schools, ${ }^{18}$ and lastly, the responsibility for post-school education. ${ }^{19}$

14 Mawdsley and Beckmann 2006 De Jure 379. As an aside, an additional complicating factor is that traditionally, where the parents are divorced, it is the custodian parent that makes the final decision regarding the schooling of the child. The AD in Calitz v Calitz 1939 AD 5663 already decided that it is the custodian parent who is in control of the minor's education (Simleit $v$ Cunliffe 1940 TPD 67 76; Mitchell $v$ Mitchell 1904 TS 130). This is the case with the choice of school (Matthee v MacGregor Auld 19814 SA 637 (Z) 640D-F; Niemeyer v De Villiers 19514 SA 100 T 103-4). Courts are hesitant to interfere with this right where it has been properly awarded and the decision is reasonable ( $F \vee F 20061$ All SA 571 (SCA)). This results in the fact that the noncustodian parent has no final say in the school that the child is attending, but remains liable for the pro rata share of the school fees (Fish Hoek Primary School para 14). Whether or not $s 31$ of the Children's Act will mitigate this problem, remains to be seen. A full discussion of this point falls outside the scope of this article, however.

15 In this regard see Veriava 2007 SAJHR 180; Reschovsky 2006 Comparative Education Review 21; Visser 2004 De Jure 358; Visser 2006 Speculum Juris 112; Visser 2007 THRHR 107.

16 Visser 2007 De Jure 156; Visser 2008 THRHR 119.

17 Springvale Ltd v Edwards 19691 SA 464 (RA).

18 Watson v Watson 19794 All SA 177 (AD); Grobbelaar v Grobbelaar 2002 JOL 9617 (T); Jones v Jones 19702 SA 308 (R); Forssman v Forssman 2007 JOL 20541 (W).

19 Van Vuuren $v$ Sam 19722 SA 633 (A); Mentz v Simpson 19904 SA 455 (A) 459; Scott $v$ Scott 1946 WLD 399; Smit v Smit 19804 All SA 52 (O); Richter v Richter 19473 All SA 118 (W) 123. 
2 Who is responsible for the payment of school fees in terms of the South African Schools Act 84 of 1996?

\subsection{SASA}

As mentioned supra, various persons are liable for the payment of school fees: the parents or guardian, or the legal custodian, or the person who undertakes to fulfil the obligation towards the learner's education at the school. ${ }^{20}$ This definition is problematic in the sense that it does not indicate which persons fall within the definition of each group, and if there is any priority system that schools should follow in approaching any of these persons. ${ }^{21}$ In the light of the Fish Hoek Primary School decision, it can, however, be stated that a school can approach any of the persons listed in the definition for the purpose of the payment of school fees. To bring about more certainty in this regard, each of the liable groups of persons is scrutinised more closely forthwith.

\subsection{Parent}

\subsubsection{Children's Act 38 of 2005}

The Children's Act is relevant with regard to defining the term "parent" in the SASA, as it purports to generally define parental responsibilities and rights in South African law. The Children's Act defines a "parent," in relation to a child, to include the adoptive parent of a child, but excludes (a) the biological father of a child conceived through the rape of or incest with the child's mother; (b) any person who is biologically related to a child by reason only of being a gamete donor for purposes of artificial fertilisation; and (c) a parent whose parental responsibilities and rights in respect of a child have been terminated. ${ }^{22}$

20 Section 1 SASA.

21 Mawdsley and Beckmann 2006 De Jure 381. The definition in a statute must be given some meaning ( $R v$ Sachs 19531 SA 392 (A) 403).

22 Section 1 Children's Act 38 of 2005. It should be noted that the responsibility of stepparents to pay school fees is excluded from this discussion. See in this regard MB v NB 20103 SA 220 (GSJ). 
As the maintenance duty of parents is part of their automatic parental responsibilities and rights, ${ }^{23}$ it follows that persons who have parental responsibilities and rights towards the child also have the duty to maintain the child. These persons are the biological mother of a child, whether married or unmarried, ${ }^{24}$ subject to the exception relating to a minor mother and surrogacy not relevant to this discussion, ${ }^{25}$ and the biological father of a child if he is married to the child's mother or was married to her at the time of the child's conception or birth or at any time in between these dates. ${ }^{26}$ The third category that qualifies as having parental responsibilities and rights is the biological father of a child, if he meets certain criteria. ${ }^{27}$ However, even where the unmarried father does not qualify for parental responsibilities and rights, his common law maintenance duty is not affected. ${ }^{28}$

The maintenance duty thus exists regardless of whether or not the parents were ever married; ${ }^{29}$ and if the parents were married, the duty also continues after the divorce of the parents. ${ }^{30}$ The basic legal principle is that both parents must maintain their children according to their respective means. ${ }^{31}$ However, where one of the parents has paid more than his or her pro rata share, he or she may recover any amount that he or she has spent in excess of his or her share of the child's maintenance from the other parent. ${ }^{32}$ This applies irrespective of whether the parents were ever married ${ }^{33}$ or how the court allocated the maintenance duty between them. ${ }^{34}$

23 Section 18(2)(d) Children's Act 38 of 2005.

24 Section 19(1) Children's Act 38 of 2005.

25 Section 19(2)-(3) Children's Act 38 of 2005.

26 Section 20 Children's Act 38 of 2005.

27 These criteria are: (a) if at the time of the child's birth he is living with the mother in a permanent life-partnership; or (b) if, regardless of whether he has lived or is living with the mother he firstly consents to be identified or successfully applies to be identified as the child's father or pays damages in terms of customary law; secondly, he contributes or has attempted in good faith to contribute to the child's upbringing for a reasonable period; and thirdly, he contributes or has attempted in good faith to contribute towards expenses in connection with the maintenance of the child for a reasonable period (s 21(1)). This section applies regardless of whether the child was born before or after the commencement of the Act (s 21(4)).

28 Section 21(2) Children's Act 38 of 2005. The father in Fish Hoek Primary School did not have parental authority (as it was then called, prior to the Children's Act) but was obliged to pay maintenance.

29 Section 15(3)(a) Maintenance Act 99 of 1998; Jordaan and Davel Law of Persons 131.

30 Bursey $v$ Bursey 19993 All SA 289 (A) 295.

31 Mentz v Simpson 19904 SA 455 (A) 457; Herfst v Herfst 19644 SA 27 (W) 130C.

32 Heaton Family Law 325.

33 Jordaan and Davel Law of Persons 132; Van der Harst v Viljoen 19771 SA 795 (C) 797-8.

34 Heaton Family Law 325; Fish Hoek Primary School para 14. 
The Children's Act specifically includes adoptive parents in the definition, and as such they are responsible for the maintenance of the adopted child. Consequently, unless the child is adopted by a step-parent who is married to or in a civil partnership with the parent of the child, the biological parents of the child no longer have the duty to maintain their biological child once the adoption is confirmed. ${ }^{35}$

Three groups of parents are excluded from the definition of "parent" in the Children's Act, namely the father of a child conceived through rape or incest, a person who is biologically related to a child by reason only of being a gamete donor for the purpose of artificial fertilisation, and a parent whose parental responsibilities and rights in respect of a child have been terminated. ${ }^{36}$ Although these persons do not have any parental responsibilities and rights towards the child, the question is if they remain liable for the maintenance of the child, including the payment of school fees?

As far as the father of a child conceived through rape or incest is concerned, he would be regarded as an unmarried father who did not qualify as a parent with the parental responsibilities and rights of $s 21(1)$. However, as stated above, his maintenance duty would continue in the light of s 21(2). To hold otherwise would be contrary to the (financial) interests of the child.

The rights of a child conceived by artificial insemination are set out in s 40 of the Children's Act:

no right, responsibility or obligation (including the duty to pay school fees) arises between a child conceived as a result of artificial insemination and any person whose gametes are used for such artificial insemination, unless the person is the woman giving birth to that child or that person was the husband of the woman at the time of artificial insemination. ${ }^{37}$

If a court terminated the parental responsibilities and rights of a biological parent, for example where the child is given up for adoption, all responsibilities and rights

35 Section 20 Child Care Act 74 of 1983. An adoption order terminates all parental responsibilities and rights between the child and his or her biological parents. See Heaton Family Law 295.

36 Section 1 Children's Act 38 of 2005. See 2.1 supra.

37 There is one exception, namely surrogacy. 
between the biological parent and the child are terminated, including the duty to support. This would usually be made clear in the court order.

It should be noted that where one or both of the parents are deceased, the duty of support, and thus the obligation to provide for the education of the child, moves to the estate of a deceased parent. ${ }^{38}$ The school could thus submit a claim in this regard to the executor of the estate for school fees, unless the child's inheritance or means is enough to meet his maintenance needs. ${ }^{39}$ In such an instance the claim for fees lies against the child herself or himself. ${ }^{40}$

\subsubsection{SASA and the non-custodian parent}

As mentioned in the introduction, the interpretation of the term "parent" in the SASA has been the focus of litigation in instances where the parents are not living together. As the SCA in the Fish Hoek Primary School case discussed various arguments raised in the earlier Roodtman matter, the discussion commences with a brief overview of the Roodtman judgment.

\subsubsection{Roodtman}

The court in Roodtman had to determine the meaning of the word "parent" in the (now repealed) Education Affairs Act (House of Assembly). ${ }^{41}$ The definition of "parent" in this statute reads: "the parent of such child or the person in whose custody the child has been lawfully placed." The court found that it should be interpreted to mean only the custodian parent, based on the interpretation of the term throughout the statute. ${ }^{42}$ The court specifically noted that to interpret the word "parent" broadly (to include the non-custodian parent) would lead to inequitable and in some cases absurd or anomalous consequences. For example, where the maintenance obligation of the non-custodian parent has been calculated with reference to all of the relevant factors, including the educational needs of the child,

38 In re Estate Visser 19483 SA 1129 (C) 1135; Heaton Family Law 326.

39 Lambrakis v Santam 20003 SA 1098 (W) 1109 I-J.

40 Van Zyl Law of Maintenance 17.

41 Education Affairs Act (House of Assembly) 70 of 1988 (Roodtman 96).

42 Roodtman 96. 
the school in which the custodian parent enrolled the child may nevertheless sue the non-custodian parent for outstanding fees - even where the non-custodian complied with the maintenance order. ${ }^{43}$ It concluded that the non-custodian parent is not liable for the payment of the outstanding school fees after a divorce. ${ }^{44}$ The court reiterated that a parent who has paid more than the pro rata share of the maintenance of the child has a claim against the other - irrespective of whether the share was apportioned by the court or not - on the basis of undue enrichment or on negotiorum gestio. $^{45}$

The Roodtman argument to an application brought in terms of the SASA (and not the Education Affairs Act) was applied in Bestuursraad van die Laerskool Sentraal, Kakamas $v$ Van Kradenburg. ${ }^{46}$

\subsubsection{Fish Hoek Primary School $v$ GW $^{47}$}

The facts of this matter occurred prior to the promulgation of the Children's Act. The facts related to the school fees of a child born of unmarried parents. The biological father in casu was neither the custodian nor the guardian of the child. He had no parental authority over the child. ${ }^{48}$ The claim for payment of the fees by the school was brought in terms of the SASA. ${ }^{49}$

The main argument by the school was that the term "parent" in the SASA should be interpreted wider than the term in the Education Affairs Act, as concluded in Roodtman. The court a quo disagreed, followed Roodtman, and found that the interpretation of the term "parent" in SASA should be the same as the interpretation of the term in the Education Affairs Act. It concluded, as did the courts in Roodtman and Van Kradenburg, that a different conclusion would lead to anomalies unintended

43 Roodtman 97.

44 Roodtman 98.

45 Roodtman 94. See discussion infra.

46 Van Kradenburg para 13.

47 Fish Hoek Primary School. For the court a quo see Fish Hoek Primary School v Welcome 20093 SA $36(C)$.

48 The term "parental authority" is used as the facts occurred prior to the Children's Act.

49 Section 40(1) SASA set out supra. 
by the legislature, particularly since the aim of these statutes is very similar and they are in pari materia. ${ }^{50}$

The Supreme Court of Appeal, however, disagreed with this finding. It based its decision on the hermeneutical principle that the literal and ordinary meaning of the words should be used. ${ }^{51}$ The SCA accordingly found that it was clear that the legislature intended a much wider meaning of the term "parent" in the section pertaining to the payment of school fees in the SASA. ${ }^{52}$ The reliance of the court $a$ quo on Roodtman was regarded as misplaced. ${ }^{53}$ It was noted that the SASA draws a distinction between parents as a general group and custodian parents, when necessary. In the section dealing with the payment of school fees reference is made to parents as a general group and not merely custodian parents. ${ }^{54}$

The SCA further argued that their interpretation of the term was in line with the constitutional demand that a court must "promote the spirit, purport and objects of the Bill of Rights when interpreting legislation." ${ }^{55}$ Mothers are historically (and currently) the primary care-givers of children and almost always become custodial parents after a divorce or breakdown of their relationship. This places an additional financial burden on them and the "sad reality is that they then become overburdened in terms of responsibilities and under-resourced in terms of means. Despite the constitutional promise of equality, the division of parenting roles continues to remain largely gender-based. ${ }^{156}$ In the light of $F v F$ supra the SCA recognised the need to be "acutely sensitive to the possibility that the different treatment of custodian parents and their non-custodian counterparts often can, and does, constitute unfair gender discrimination. ${ }^{57}$ The court found that to interpret the SASA to exclude the non-custodian parent from its operation would frustrate the realisation of the constitutional goal of gender equality. ${ }^{58}$

50 Fish Hoek Primary School (a quo) 41, 43.

51 Fish Hoek Primary School para 6-8. The discussion of the court regarding the interpretation of one statute in the light of the preceding statute is disregarded for purposes of this discussion.

52 Fish Hoek Primary School paras 5, 8.

53 Fish Hoek Primary School para 5.

54 Fish Hoek Primary School para 12.

55 Section 39(2) Constitution of the Republic of South Africa, 1996.

56 Fish Hoek Primary School para 13.

57 Fish Hoek Primary School para 13.

58 Fish Hoek Primary School para 13. 
The court continued that their interpretation is in line with the common law duty on both parents to support their children in accordance with their respective means - a duty that extends to the educational needs of the child. ${ }^{59}$ Furthermore, as the SASA provides for compulsory education, a wider interpretation (thus burdening both parents with the duty to pay school fees) is also in line with the constitutional principle of the best interests of the child. ${ }^{60}$

It, unquestionably, is in the best interests of the child that a non-custodian parent, who is unwilling, yet has the means to pay his child's school fees, should be made to do so, if necessary, by the injunction of an order of a competent court. ${ }^{61}$

The court noted that a different decision would saddle the custodian parent with all of the responsibility and that, although there might be a claim against the non-custodian parent for the amount paid more than her pro rata share, such a claim is often "illusory." ${ }^{22}$ The court concluded that the sad reality is that many custodian parents do not have the means to pay school fees. If the school was not allowed to claim in these instances from the non-custodian parent, the result would be that the school would have to shoulder the loss or that the school would have to mulch other parents with the additional burden, which would be to the detriment of other learners. ${ }^{63}$ It noted that it was clear that the intention of the legislature was to cast the net as wide as possible to include as many persons as possible, to afford the school the maximum protection. ${ }^{64}$

The decision by the SCA should be welcomed. It clarified the uncertainty created in the Roodtman judgment. The crux is that the school is entitled to claim payment from both parents, regardless of the relationship and history between the parents, as both parents are liable for maintenance in terms of the common law. This is so, regardless of whether or not there is an existing maintenance order or settlement agreement.

59 Fish Hoek Primary School para 14.

60 Section 28(2) Constitution of the Republic of South Africa, 1996.

61 Fish Hoek Primary School para 14.

62 Fish Hoek Primary School para 14.

63 Fish Hoek Primary School para 14.

64 Fish Hoek Primary School para 14. 
Three additional issues are noteworthy from the judgment: the role of the concept of the best interests of the child, the broader gender issues, and the dilemma for divorced parents.

The court in Fish Hoek Primary School reiterated that the constitutional principle that the best interests of the child should be of paramount importance in all matters ${ }^{65}$ should be decisive, and is served by holding the non-custodian parent liable for the payment of school fees. ${ }^{66}$ The impact of the judgment on the non-custodian parent is that a liability is created for a parent without necessarily any input of that parent as to the school which the child attends and irrespective of whether or not the parent is in compliance with an existing and updated maintenance order. ${ }^{67}$ It is submitted that this is correct, as any negative impact on the rights of the non-custodian parent is overshadowed by the rights of the child to a suitable education. The non-custodian parent would be able to claim from the other parent any amount paid in excess of his or her pro rata share of the maintenance obligation. The difference is that the Supreme Court of Appeal has shifted the practical burden to reclaim any such an excess amount from the custodian parent to the non-custodian parent.

The sensitivity of the court to the gender issues is laudable and in line with the Constitutional Court decision in Bannatyne $v$ Bannatyne, ${ }^{68}$ where the engendered nature of maintenance was highlighted. The Constitutional Court noted:

... on the breakdown of a marriage or similar relationship it is almost always mothers who become the custodial parent and have to care for the children. This places an additional financial burden on them and inhibits their ability to obtain remunerative employment. Divorced or separated mothers accordingly face the

65 S 28(2) Constitution of the Republic of South Africa, 1996.

66 Joubert $v$ Joubert 2008 JOL 21929 (C) para 35.

67 The effect of the judgment is that courts can now, in contravention of an existing (maintenance) court order, order that school fees must be paid by the non-custodian parent. Such a parent would probably already be paying an amount of maintenance in terms of a previous court order. This (first) court order, whether it is a high court or maintenance court order, would normally be a result of an investigation made into the reasonableness of the expense and after taking into account all of the relevant factors such as the means of the parties and their standard of living. The (second) court, which orders the non-custodian to pay school fees, thus in effect "overrules" the existing order without any investigation. This seems unsatisfactory. One way to mitigate this problem could be to refer the issue to the maintenance court, as the payment of school fees would presumably qualify in terms of s 6(1)(b) of the Maintenance Act as "good cause for the substitution of a maintenance order." However, this option would decrease the effectiveness of the solution embraced by the court.

68 Bannatyne v Bannatyne 20032 BCLR 111 (CC) paras 29-30. 
double disadvantage of being overburdened in terms of responsibilities and underresourced in terms of means. Fathers, on the other hand, remain actively employed and generally become economically enriched. These disparities undermine the achievement of gender equality which is a founding value of the Constitution. The enforcement of maintenance payments therefore not only secures the rights of children, it also upholds the dignity of women and promotes the foundational values of achieving equality and non-sexism. Fatalistic acceptance of the insufficiencies of the maintenance system compounds the denial of rights involved. Effective mechanisms for the enforcement of maintenance obligations are thus essential for the simultaneous achievement of the rights of the child and the promotion of gender equality.

It is submitted that the same argument is applicable to the issue of the payment of school fees. In practice it would assist schools in their pursuit of the payment of school fees, as the liability is that of all of the parents, regardless of their marital status and the relationships inter se. The SCA did what was required by the Constitutional Court, namely to create an additional mechanism for the enforcement of maintenance obligations, albeit only for a part of them.

Although this judgment related in the first instance to parents who were never married, it is submitted that the definition of a "parent" is sufficiently wide to include divorced or separated parents. This judgment creates a dilemma for divorced or divorcing parties. A settlement agreement that is made an order of court may or may not specify who is liable for school fees. The courts are not ad idem in this regard. In Du Toit $v$ Du Toif ${ }^{69}$ the court did not want to make a special order in addition to the general maintenance amount, as doing that could have made the total maintenance amount unreasonably large. However, in Schmidt $v$ Schmidt ${ }^{70}$ the court disagreed with this position (in a judgment later confirmed by the SCA). It noted that as school fees fluctuate constantly it would not be practical to quantify this amount at the time of the divorce. ${ }^{71}$ In the light of Fish Hoek Primary School, the parties were to be made aware that the school could claim school fees from either parent or both parents in terms of the SASA, and that the arrangement of the parties inter se was irrelevant to the school.

69 Du Toit v Du Toit 19913 SA 856 (O) 860.

70 Schmidt v Schmidt 19962 SA 211 (W).

71 See also inter alia Cohen v Cohen 20033 SA 337 (SCA); Power v Power 2009 JOL 23848 (KZN); and Kooverjee $v$ Kooverjee $2006 \mathrm{JOL} 17320$ (C). 


\subsection{Guardian}

The second group of persons who are liable for school fees in terms of the SASA is "guardians." The parental responsibilities and rights of parents as discussed supra would, as a rule, include guardianship of the child, unless the court has ordered otherwise. ${ }^{72}$ Even after a divorce, unless sole guardianship was awarded to one parent in terms of the Divorce $A c t,{ }^{73}$ both parents retain guardianship. One parent would, however, be appointed as the custodian.

In addition, a guardian may also be a person appointed by the court. This may be after the guardianship of the parents is terminated, or after the death of the parents of the child. ${ }^{74}$

It is uncertain whether the SASA definition refers to any person that has guardianship over a child or only to those guardians who are not parents. In the light of the hermeneutical principle that every word is important, ${ }^{75}$ it is submitted that the "guardian" in the definition would refer only to guardians who are not parents. Although this overlapping of terms is not of consequence for the purposes of the payment of school fees, it is an example of the legislature's being overly cautious and adding persons ex abundanti cautela in guarding against any person's being omitted. $^{76}$

\subsection{Custodian}

The same argument is applicable to the custodian's being liable for the payment of school fees, as the custodian is generally a person with parental responsibilities and rights. The custodian of a child is usually the person who is responsible for the dayto-day care and control of the child. ${ }^{77}$ The custodian is appointed by the court upon

72 Section 18(2) Children's Act 38 of 2005.

73 Section 6 Divorce Act 70 of 1979.

74 Heaton Family Law 302.

75 Botha Statutory Interpretation 69.

76 Botha Statutory Interpretation 69.

77 Heaton Family Law 172; Martin v Mason 19491 PH B9 (N) 24. See also the definition of "care" in s 1 Children's Act 38 of 2005. 
the separation of the parents pending divorce, after a divorce,${ }^{78}$ or even where they never married. ${ }^{79}$ However, the High Court may place a child in the care (the custody) of a third party who is not the parent of the child. ${ }^{80}$

Visser ${ }^{81}$ rightly argues that the word "custodian" in this instance should not refer to a parent or guardian but to a third party. This argument is in line with the Children's Act, ${ }^{82}$ which makes provision for a "care-giver," meaningt any person other than a parent and guardian, who factually cares for a child, including a foster parent. A person who cares for a child means any person other than a parent or guardian, who factually cares for a child; a person who cares for a child whilst the child is in temporary safe care; the person at the head of a child and youth care centre where a child has been placed; the person at the head of a shelter; a child and youth care worker who cares for a child who is without appropriate family care in the community; and the child at the head of a child-headed household. ${ }^{83}$ Although the Children's Act does not require that such a person would be responsible for the maintenance of the child, the SASA does require the person to pay the school fees unless the person is exempted.

\subsection{The person who undertakes responsibility}

A person who undertakes the responsibility of a parent, guardian or custodian is also liable for the payment of school fees in terms of the SASA. This is the broadest

78 Section 5(1) Matrimonial Affairs Act 37 of 1953; s 6(3) Divorce Act 70 of 1979.

79 Heaton Family Law 289.

80 Section 15 Child Care Act 74 of 1983. The Children's Act (s 23) provides for the assignment of the care (the custody) of the child to an interested person by order of court, but this section has not yet become operational.

81 Visser 1997 TSAR 627. See also Mawdsley and Beckmann 2006 De Jure 382.

82 Section 1 as read with s 32 Children's Act 38 of 2005.

83 Section 1 Children's Act 38 of 2005. S 32 makes provision for the care of a child by a person not holding parental responsibilities and rights. S 32(1)-(2) provides that, subject to $s 129$ (consent to medical treatment and surgical operation) a care-giver may exercise any parental responsibilities and rights reasonably necessary to safeguard the child's health, well-being and development; and to protect the child from maltreatment, abuse, neglect, degradation, discrimination, exploitation, and any other physical, emotional or mental harm or hazards, including the right to consent to any medical examination or treatment of the child if such consent cannot reasonably be obtained from the parent or guardian of the child. A court may limit or restrict the parental responsibilities and rights of such a person (s 32(3)). However, such a person may not hold himself or herself out as the biological or adoptive parent of the child, or deceive the child or any other person into believing that that person is the biological or adoptive parent of the child ( $\mathrm{s}$ $32(4))$. 
category of the definition and the only one specifically directed at education. ${ }^{84}$ Although not defined, this person is, seemingly, a third party who is not the custodian but who voluntarily takes on the responsibility of the child and for this purpose pays or agrees to pay the school fees of the child. In practice this would presumably be an extended family member not liable for maintenance, such as a step-parent. ${ }^{85}$

\subsection{Conclusion}

The SASA casts the net of persons liable for school fees very wide, to include parents, guardians, custodians and those who undertake the responsibility. These groups seem to overlap to some extent, depending on the interpretation of the terms ${ }^{86}$ Regardless of the interpretation, though, it seems as if any of these persons could be approached by a school for the payment of school fees.

\section{$3 \quad$ Alternative legal foundations for liability for school fees}

\subsection{Introduction}

Apart from the liability of a parent in terms of the SASA as read with the Children's Act and case law as set out above, there are also other bases for a claim against a parent. These include contractual liability, liability based on the principle of household necessaries irrespective of the matrimonial property system of the parents, the principle of stipulatio alteri (where the obligation to pay school fees is set out in a court order), ${ }^{87}$ and negotiorum gestio or undue enrichment. Each of these is briefly touched upon in turn below.

84 Mawdsley and Beckmann 2006 De Jure 383.

85 It should be noted by schools that where the person is not legally automatically liable to make such payments it would be an act of vigilance to confirm the arrangement contractually.

86 Mawdsley and Beckmann 2006 De Jure 382.

87 Roodtman 94-5. 


\subsection{Contractual obligation}

Visser $^{88}$ notes that it is practice in most public schools to require that at least one parent sign an agreement to pay school fees. As this obligation already exists in the SASA ${ }^{89}$ this contract merely affirms that position and may create a further obligation. Where a contract would be useful includes instances where the enrolling person does not qualify as a parent in terms of the SASA for the purpose of the payment of school fees. ${ }^{90}$

Litigation about the non-payment of school fees has not been uncommon in the South African law, and the disputes in earlier cases were generally contractual in nature. ${ }^{91}$

\subsection{Household necessaries - married parents (or parents in a civil partnership) living within the same household}

Where the parents are married or in a civil partnership and there is a joint household, both parents would be liable for school fees, irrespective of who the contracting party was that enrolled the child in the school, ${ }^{92}$ based on the principle of household necessaries. During the marriage, a non-contracting party may be held liable for household necessaries for the joint household. ${ }^{93}$ The usual requirements should be met: firstly there must be a valid marriage (or civil partnership) $;{ }^{94}$ secondly, there must be a joint household; and thirdly, the fees must be regarded as household necessaries. ${ }^{95}$ The decision as to whether or not the school fees would be regarded as household necessaries depends on various factors such as the practice and customs in the area, the social status of the parties, and the parents' past standard

88 Visser 2004 THRHR 533-537.

89 Section 40(1) SASA.

90 Visser 2004 THRHR 537.

91 Hart v Forman 190522 SC 284; Durr v Schumann 191027 SC 21; Pepler v Molteno School Board 1912 CPD 519; Smith v Carsen 1916 EDL 26; Slivkin v Hillel College 1922 TPD 402.

92 Roodtman 98.

93 Sections 17(5) and 23(5) Matrimonial Property Act 88 of 1984 for marriages in and out of community of property respectively (Roodtman 95); Heaton Family Law 49.

94 Section 13 Civil Union Act, 17 of 2006.

95 Heaton Family Law 50. 
of living. ${ }^{96}$ If the situation does not conform to these criteria the debt cannot be regarded as household necessaries or where there is no joint household, the third party (school) may not use this foundation as the basis for a claim. ${ }^{97}$ It is, however, unlikely that the school would base its claim on household necessaries, given the existence of the SASA provisions.

\subsection{Stipulatio alteri}

The court in Roodtman noted obiter that where the deed of settlement expressly provides for the payment of school fees by the non-custodian parent the third party supplier might be able to claim against the non-custodian parent on the basis of the stipulatio alteri. ${ }^{98}$ No firm views on the issue were expressed, however. ${ }^{99}$

A stipulatio alteri is generally a provision in a contract between a promissory and a promisee with a positive intention to empower a third party to adopt and become a party to the contract if he/she so wishes. ${ }^{100}$

This issue was canvassed before the SCA in Bursey $v$ Bursey. ${ }^{101}$ In this matter it was argued that a divorce settlement agreement included in the court order (that included the duty to pay maintenance for the children) constituted a stipulatio alteri in favour of the child, with the result that only the (major) child had the right to enforce the obligation to pay maintenance. The court disagreed with this submission since the original agreement had no intention of conferring any right on the child other than those rights flowing from the common law duty to maintain. ${ }^{102}$ The court a quo found (and the SCA agreed) that there was no "positive intention to empower the third party to adopt and become a party to the contract if he wishes," as required for the formation of a stipulatio alteri. ${ }^{103}$

96 Heaton Family Law 50; Reloomel v Ramsay 1920 TPD 371 374; Voortrekker Winkels (Kooperatief) Bpk v Pretorius 19511 SA 730 (T) 734 D-E.

97 Roodtman 94-5.

98 Roodtman 95. See Boezaart Child Law 79 and discussion infra.

99 Roodtman 95.

100 Christie Law of Contract 266-267.

101 Bursey $v$ Bursey $1999 \mathrm{JOL} 4717$ (A) 16 (hereinafter referred to as Bursey).

102 Bursey 16.

103 Bursey v Bursey 19974 All SA 580 (E) 592; Christie Law of Contract 295. 
In the light of Bursey it is submitted that a settlement agreement, made an order of court, is not a stipulatio alteri. The same would also be true for parenting plans determined in terms of the Children's Act, ${ }^{104}$ that include a maintenance obligation. A school would thus not be able to use the principle of stipulatio alteri to claim school fees from a parent.

\subsection{Negotiorum gestio}

The next possible foundation for a school fees claim against a parent liable for the maintenance of the child is negotiorum gestio. It can be argued that where a third party fulfils the parental duty of support on behalf of a parent by supplying a minor with necessaries like food and clothing (or school fees) the parent may be liable on the basis of negotiorum gestio. ${ }^{105}$

Joubert and Van Zy| ${ }^{106}$ describe negotiorum gestio as "the voluntary management by one person (the negotiorum gestor) of the affairs of another (the dominus negotii) without the consent or even knowledge of the latter." The crux is that the person is not authorised to act. ${ }^{107}$ The intention is to manage the affairs of another and to recover from the dominus any amount spent in this regard. ${ }^{108}$ The act of the negotiorum gestor may relate to the payment of the debts of the dominus or involve the maintenance of the children. ${ }^{109}$ If these requirements are met and the negotiorum gestor acts in a useful and reasonable manner ${ }^{110}$ and renders an account, ${ }^{111}$ he/she is entitled to claim all of the necessary and useful expenses incurred by him. ${ }^{112}$

It is submitted that the court in Roodtman was correct to note, albeit obiter, that this possibility should extend to the school fees of the child. Where a third party thus pays the school fees of the child without the consent and knowledge of the liable person (parent), any amount spent can then be reclaimed from the liable party in

104 Section 33(3)(b) and (d) Children's Act 38 of 2005.

105 Sonnekus Unjustified Enrichment 156; Cockrell "Contracts" 798.

106 Joubert and Van Zyl "Mandate and Negotiorum Gestio" paras 17-23.

107 Joubert and Van Zyl "Mandate and Negotiorum Gestio" para 21.

108 Joubert and Van Zyl "Mandate and Negotiorum Gestio" para 23.

109 Joubert and Van Zyl "Mandate and Negotiorum Gestio" para 19.

110 Joubert and Van Zyl "Mandate and Negotiorum Gestio" para 24.

111 Joubert and Van Zyl "Mandate and Negotiorum Gestio" para 27.

112 Joubert and Van Zyl "Mandate and Negotiorum Gestio" para 30. 
terms of the principle of negotiorum gestio. However, where the negotiorum gestor forbids the third party from paying the amount, a claim based on this principle would be excluded. ${ }^{113}$ Whether a party would, in these instances, be entitled to the amount paid based on unjustified enrichment is uncertain and would depend on if it would "'do justice between man and man" and if there were "some just cause" for disregarding the wishes of the dominus. ${ }^{114}$

\subsection{Unjustified enrichment}

Various authors and courts have noted that a claim for the payment of maintenance (and, for our purposes, school fees) may be based on the principle of unjustified or undue enrichment. The argument is that where one person, the non-paying parent, unjustly obtains a patrimonial advantage at the expense of another person, the enriched person must then reimburse the impoverished one. ${ }^{115}$

The factors to be proven are 1) that there must be actual enrichment of the one party, 2) the enrichment must be at the expense of the impoverished party, 3) the enrichment must be unfounded, and 4) there must be no rule of law that denies the right of restitution of the impoverished, despite the presence of the other elements. ${ }^{116}$ Sonnekus ${ }^{117}$ states that enrichment may be incurred from a diminishing of expenses that would, in all probability, not have taken place if it had not been for the enriching act (the saving of disbursements). It is submitted that the non-payment of school fees would fall into this category.

Where, however, the money was spent on necessaries which would have had to be provided in any event, it matters not that these have been consumed at the time of action, for the enrichment consists not in the things themselves but in the saving of moneys which would have otherwise have had to be applied to their purpose.... (I)f the necessaries would have been paid for by a parent whose duty it was to support the minor, it is the parent, not the minor, who is liable to the other party, either based on unjust enrichment or on the principle of negotiorum gestio. ${ }^{118}$

113 Joubert and Van Zyl "Mandate and Negotiorum Gestio" para 39.

114 Joubert and Van Zyl "Mandate and Negotiorum Gestio" para 39.

115 Jordaan and Davel Law of Persons 80; see also Heaton Law of Persons 103; Pretorius $v$ Van Zyl 1927 OPD 226.

116 Sonnekus Unjustified Enrichment 41-42; Du Bois Principles of South African Law 1046.

117 Sonnekus Unjustified Enrichment 44.

118 Cockrell "Contracts" 813. 
The amount of enrichment claimed is determined at the time of litis contestatio. ${ }^{119}$ The basis for the liability is not a juristic act but solely enrichment that cannot be justified on any legal ground. ${ }^{120}$ The argument is that the enriched party (the nonpaying parent) would have had to pay the necessaries (the school fees) out of his or her own pocket and as such the enrichment is equal to the costs of the necessaries (the school fees). ${ }^{121}$

Although a claim for the maintenance of a minor was turned down in Van $Z y l v$ Serfontein, ${ }^{122}$ Sonnekus rightly states that this was not on principle but as a result of poorly drafted pleadings. ${ }^{123}$

Visser ${ }^{124}$ argues that the challenge is to balance the right to liberty of a defendant (a non-paying parent) who has had the enrichment imposed on him or her, and the right of the plaintiff (the school) which has expended money and made the defendant richer. It is submitted that with school fees it is an easier balance to draw, based on the best interests of the child and gender equity, as discussed supra.

\section{Prescription}

Schools should be reminded that a debt for school fees would be extinguished after a period of three (3) years, ${ }^{125}$ unless the prescription period is interrupted. The three years commence as soon as the debt is due. ${ }^{126}$ With school fees this would usually be the enrolment date or the date set in the contract. If the claim is based on negotiorum gestio or unjustified enrichment, the prescription commences after the administration of the affairs has been completed or the service was supplied. ${ }^{127}$

119 Du Bois Principles of the South African Law 1048; Jordaan and Davel Law of Persons 81.

120 Jordaan and Davel Law of Persons $81 \mathrm{fn} 204$.

121 Heaton Law of Persons 103-104.

122 Van Zyl v Serfontein 19922 SA 450 (C).

123 Sonnekus Unjustified Enrichment 64, 275 fn 233, 313-314. A full discussion of this judgment falls outside the scope of this note.

124 Visser Unjustified Enrichment 643-644.

125 Section 11(d) as read with s 10 Prescription Act 68 of 1969.

126 Section 12(1) Prescription Act 68 of 1969.

127 Joubert and Van Zyl "Mandate and Negotiorum Gestio" para 34; Visser Unjustified Enrichment 75; Cockrell "Contracts" 815 respectively. In the matter of Vryburg School Board v Cloete 19553 SA 355 (A) the claim for the refunding of assistance rendered in respect of lodgings for school children in terms of Ordinance 5 of 1921 (C) was found to have prescribed within three years after the board and lodging was supplied, based on the previous Prescription Act 18 of 1943. A 


\section{Conclusion}

The enforcement of the payment of school fees in South Africa is essential to the rights of children to receive suitable education. It is simply not possible for the State to provide proper education to all at state expense. Although most parents, whatever their relationship, are in agreement on the placement of a child at school and agree to the payment of the school fees, there are instances where a parent is not willing to fulfil his/her responsibilities in this regard even if he/she is able to do so.

The SASA, as read with the Children's Act and the judgment of Fish Hoek Primary School, clarified the responsibility of particular persons to be directly held liable for the payment of school fees, irrespective of their relationship. The SCA decision should particularly be welcomed for the sensitive nature in which the gender issues were dealt with. It is also laudable that schools now have a variety of legal options available to them for their use in the pursuit of the fees they need to collect in order to be able provide a satisfactory standard of education for the learners for whom they are responsible. In the words of Visser, ${ }^{128}$ "the raising and proper use of school fees is important in the promotion of quality education." 


\section{Bibliography}

Boezaart Child Law

Boezaart T (ed) Child Law in South Africa (Juta Claremont 2009)

Botha Statutory Interpretation

Botha C Statutory Interpretation - An Introduction for Students $4^{\text {th }}$ ed (Juta Cape Town 2005)

Cockrell "Contracts"

Cockrell A "Capacity to perform juristic acts: contracts" in Van Heerden B, Cockrell A and Kneightley R (eds) Boberg's Law of Persons and the Family $2^{\text {nd }}$ (Juta Kenwyn 1999) 756-834

Du Bois Principles of South African Law

Du Bois $\mathrm{F}$ (ed) Wille's Principles of South African Law $9^{\text {th }}$ ed (Juta Cape Town 2007)

Christie Law of Contract

Christie RH The Law of Contract in South Africa $5^{\text {th }}$ ed (LexisNexis Butterworths Durban 2006)

Heaton Family Law

Heaton J The South African Family Law $3^{\text {rd }}$ ed (LexisNexis Butterworths Durban 2010)

Heaton Law of Persons

Heaton J The South African Law of Persons $3^{\text {rd }}$ ed (LexisNexis Butterworths Durban 2008) 
Jordaan and Davel Law of Persons

Jordaan RA and Davel CJ Law of Persons (Juta Wetton 2005)

Joubert and Van Zyl "Mandate and Negotiorum Gestio"

Joubert DJ and Van Zyl DH (revised by Van Zyl) "Mandate and Negotiorum Gestio" in Joubert WA, Faris JA and Harms LTC (eds) The Law of South Africa $2^{\text {nd }}$ ed (LexisNexis Durban 2009) Vol 17(1)

Mawdsley and Beckmann 2006 De Jure

Mawdsley RD and Beckmann $\mathrm{J}$ "Who is a parent for purposes of making educational decisions on behalf of children? A comparison of approaches taken by the United States and South Africa" 2006 De Jure 354-384

Reschovsky 2006 Comparative Education Review

Reschovsky A "Financing schools in the New South Africa" 2006 Comparative Education Review 21-45

Sonnekus Unjustified Enrichment

Sonnekus JC Unjustified Enrichment in South African Law (LexisNexis Durban 2008)

Van Zyl Law of Maintenance

Van Zyl L Handbook of the South African Law of Maintenance (LexisNexis Durban 2005)

Veriava 2007 SAJHR

Veriava $F$ "The amended legal framework for school fees and school funding: A boon or a barrier" 2007 SAJHR 180-194 


\section{Visser 1997 TSAR}

Visser PJ "Some principles regarding the rights, duties and functions of parents in terms of the provisions of the South African Schools Act 84 of 1996 applicable to public schools" 1997 TSAR 626-636

\section{Visser Unjustified Enrichment}

Visser D Unjustified Enrichment (Juta Cape Town 2008)

Visser 2004 De Jure

Visser PJ "Aspects of School Fees at Public Schools" 2004 De Jure 358-362

Visser 2004 THRHR

Visser PJ "Who is legally liable to pay school fees? Governing Body, Gene Louw Primary School v Roodtman 20041 SA 45 (C)" 2004 THRHR 533-537

Visser 2006 Speculum Juris

Visser PJ "Notes on the intended reform of the law relating to school fees" 2006 Speculum Juris 112-117

Visser 2007 De Jure

Visser PJ "Some aspects of the regulations relating to the exemption of parents from the payment of school fees in public schools" 2007 De Jure 156160

Visser 2007 THRHR

Visser PJ "A note on aspects of the legal principles governing school fees in public schools" 2007 THRHR 107-114

Visser 2008 THRHR

Visser PJ "The exemption of a parent from paying public school fees with reference to the position of a divorcee" 2008 THRHR 119-124 


\section{Register of court cases}

Bannatyne v Bannatyne 20032 BCLR 111 (CC)

Bestuursraad van die Laerskool Sentraal, Kakamas v Van Kradenburg 2008 JOL 21631 (NC)

Bestuursliggaam van Gene Louw Laerskool v Roodtman 20032 All SA 87 (C)

Bursey v Bursey 19974 All SA 598 (E) [also reported as B v B 19974 SA 1018(SE)] (a quo)

Bursey v Bursey 19993 SA 289 (SCA) [also reported as Bursey v Bursey 1999 JOL $4717(\mathrm{~A})$ and $B \vee B 19992$ All SA $289(\mathrm{~A})]$

Calitz v Calitz 1939 AD 56

Cohen $v$ Cohen 20033 SA 337 (SCA)

Durr v Schumann 1910)27 SC 21

Du Toit $v$ Du Toit 19913 SA 856 (O)

$F v F 20061$ All SA 571 (SCA)

Fish Hoek Primary School v Welcome 20093 SA 36 (C)

Fish Hoek Primary School v GW 2009 JOL 24624 (SCA)

Forssman v Forssman 2007 JOL 20541 (W)

Grobbelaar v Grobbelaar 2002 JOL 9617 (T)

Hart v Forman 190522 SC 284

Herfst $v$ Herfst 19644 SA 27 (W)

In re Estate Visser 19483 SA 1129 (C)

Jones $v$ Jones 19702 SA $308(\mathrm{R})$

Joubert $v$ Joubert 2008 JOL 21929 (C)

Kooverjee v Kooverjee 2006 JOL 17320 (C)

Lambrakis v Santam 20003 SA 1098 (W)

Martin v Mason $19491 \mathrm{PH}$ B9 (N)

Matthee v MacGregor Auld 19814 SA 637 (Z)

MB v NB 20103 SA 220 (GSJ)

Mentz v Simpson 19904 SA 455 (A)

Mitchell v Mitchell 1904 TS 130

Niemeyer v De Villiers 19514 SA 100 (T)

Pepler v Molteno School Board 1912 CPD 519

Power v Power 2009 JOL 23848 (KZN) 
Pretorius v Van Zyl 1927 OPD 226

$R v$ Sachs 19531 SA $392(\mathrm{~A})$

Reloomel v Ramsay 1920 TPD 371

Richter v Richter 19473 All SA 118 (W)

Schmidt $v$ Schmidt 19962 SA 211 (W)

Scott $v$ Scott 1946 WLD 399

Simleit v Cunliffe 1940 TPD 67

Slivkin v Hillel College 1922 TPD 402

Springvale Ltd v Edwards 19691 SA 464 (RA)

Smith v Carsen 1916 EDL 26

Smit v Smit 19804 All SA 52 (O)

Van der Harst $v$ Viljoen 19771 SA 795 (C)

Van Vuuren v Sam 19722 SA 633 (A)

Van Zyl v Serfontein 19922 SA 450 (C)

Voortrekker Winkels (Ko-operatief) Bpk v Pretorius 19511 SA 730 (T)

Vryburg School Board v Cloete 19553 SA 355 (A)

Watson $v$ Watson 19794 All SA 177 (AD)

\section{Register of legislation and government documents}

Child Care Act 74 of 1983

Children's Act 38 of 2005

Civil Union Act 16 of 2006

Constitution of the Republic of South Africa, 1996

Divorce Act 70 of 1979

Education Affairs Act (House of Assembly) 70 of 1988 (repealed)

Maintenance Act 99 of 1998

Matrimonial Affairs Act 37 of 1953

Matrimonial Property Act 88 of 1984

Prescription Act 18 of 1943

Prescription Act 68 of 1969

South African Schools Act 84 of 1996 


\section{List of abbreviations}

SAJHR South African Journal on Human Rights

SASA South African Schools Act

THRHR Tydskrif vir Hedendaagse Romeins-Hollandse Reg/Journal of Contemporary Roman-Dutch Law

TSAR Tydskrif vir die Suid-Afrikaanse Reg/Journal of South African Law 